\title{
Characterization and ligand identification of a membrane progesterone receptor in fungi: existence of a novel PAQR in Sporothrix schenckii
}

Waleska Gonzalez-Velazquez ${ }^{1}$, Ricardo Gonzalez-Mendez² and Nuri Rodriguez-del Valle ${ }^{1 *}$

\begin{abstract}
Background: Adaptive responses in fungi result from the interaction of membrane receptors and extracellular ligands. Many different classes of receptors have been described in eukaryotic cells. Recently a new family of receptors classified as belonging to the progesterone-adiponectin receptor (PAQR) family has been identified. These receptors have the seven transmembrane domains characteristic of G-protein coupled receptors, but their activity has not been associated directly to G proteins. They share sequence similarity to the eubacterial hemolysin III proteins.

Results: A new receptor, SsPAQR1 (Sporothrix șchenckii progesterone-adiponecting receptor1), was identified as interacting with Sporothrix schenckii G protein alpha subunit SSG-2 in a yeast two-hybrid assay. The receptor was identified as a member of the PAQR family. The cDNA sequence revealed a predicted ORF of 1542 bp encoding a 514 amino acids protein with a calculated molecular weight of $57.8 \mathrm{kDa}$. Protein domain analysis of SsPAQR1 showed the 7 transmembrane domains (TM) characteristic of G protein coupled receptors and the presence of the distinctive motifs that characterize PAQRs. A yeast-based assay specific for PAQRs identified progesterone as the agonist. S. schenckii yeast cells exposed to progesterone $(0.50 \mathrm{mM})$ showed an increase in intracellular levels of $3^{\prime}, 5^{\prime}$ cyclic adenosine monophosphate (CAMP) within the first min of incubation with the hormone. Different progesterone concentrations were tested for their effect on the growth of the fungus. Cultures incubated at $35^{\circ} \mathrm{C}$ did not grow at concentrations of progesterone of $0.05 \mathrm{mM}$ or higher. Cultures incubated at $25^{\circ} \mathrm{C}$ grew at all concentrations tested $(0.01 \mathrm{mM}-0.50 \mathrm{mM})$ with growth decreasing gradually with the increase in progesterone concentration.

Conclusion: This work describes a receptor associated with a G protein alpha subunit in S. schenckii belonging to the PAQR family. Progesterone was identified as the ligand. Exposure to progesterone increased the levels of cAMP in fungal yeast cells within the first min of incubation suggesting the connection of this receptor to the cAMP signalling pathway. Progesterone inhibited the growth of both the yeast and mycelium forms of the fungus, with the yeast form being the most affected by the hormone.
\end{abstract}

\section{Background}

Heterotrimeric $(\alpha \beta \gamma)$ guanine nucleotide binding proteins (G proteins) constitute a family of regulatory GTP hydrolases associated with the cytoplasmic face of the plasma membrane [1-4]. Their activity is characterized by a cycle of GTP-binding and hydrolysis. The GTP- and GDPbound complexes define the active and inactive states of

* Correspondence: nuri.rodriguez@upr.edu

${ }^{1}$ Department of Microbiology and Medical Zoology, Medical Sciences Campus, University of Puerto Rico, PO Box 365067, San Juan PR 00936-5067, USA

Full list of author information is available at the end of the article the G proteins, respectively. The binding of specific ligands to transmembrane receptors activates the heterotrimeric $G$ protein subunits that are responsible for the flow of information in many eukaryotic signal transduction pathways [5]. The traditional G proteins coupled receptors (GPCRs) share a characteristic topological structure of seven transmembrane domains and recognize diverse extracellular signals. The cytoplasmic C-terminal region contains the $\mathrm{G} \alpha$ binding activity.

Recently, a new class of seven transmembrane receptors has been identified in humans and other vertebrates

\section{() Biomed Central}


and has been classified as belonging to the PAQR superfamily (progestin-adipoQ receptors) [6-10]). Their activity has not been directly associated to heterotrimeric $\mathrm{G}$ proteins but indirect evidence suggests that they might be associated to $G$ protein alpha subunits $[11,12]$.

The PAQR superfamily includes three classes of membrane receptors. Class I PAQRs are adiponectin receptors and include: AdipoR1 (PAQR 1), AdipoR2 (PAQR 2), PAQR 3 and PAQR 6 [13]. These receptors respond to adiponectin that is an insulin-sensitizing peptide hormone found in vertebrates $[14,15]$. Low serum adiponectin levels have been identified as a high risk factor for type 2 diabetes and other complications such as atherosclerosis and hepatic steatosis. Adiponectin has been reported to have a positive effect on insulin sensitivity and energy metabolism [16].

Class II PAQRs respond to progesterone and include: $\mathrm{mPR} \alpha(\mathrm{PAQR} 7), \mathrm{mPR} \beta$ (PAQR 8) and mPR $\gamma$ (PAQR 5) [13]. For a long time progesterone had been observed to mediate immediate cellular effects not attributable to the classical nuclear progesterone receptors that involve mRNA and new protein synthesis [10]. With the identification of the PAQR membrane receptors for progesterone the rapid effects of this hormone, not dependent on gene transcription, can be explained [6]. The response of steroid membrane receptors can be rapid, as in the case of sperm hypermotility, or can occur over a prolonged period of time as in the case of oocyte maturation in fish [17] and amphibians [18,19].

Class III are the hemolysin III-related receptors that have the deepest evolutionary roots but whose agonists are not known, these are PAQR 10 and PAQR 11 [20] and the bacterial hemolysin III large class of proteins, expressed in many bacterial species [7]. The latter have been shown to induce cytolysis of eukaryotic cells by pore formation [21].

In Saccharomyces cerevisiae, the Izh genes encode membrane proteins that also belong to the ubiquitous protein family that includes hemolysin III and vertebrate membrane PAQR homologues. The Izh family (implicated in zinc homeostasis) consists of 4 different proteins: Izh1, Izh2, Izh3 and Izh4. All but the Izh1 have the 7 transmembrane domains of the PAQRs [22]. The agonist for Izh2 has been identified as osmotin, a plant defense protein that is a homologue of adiponectin [23]. Yeast mutants of the Izh proteins exhibit defects in zinc tolerance. Izh proteins have been reported to be regulated by exogenous fatty acids, suggesting a role in lipid metabolism [24]. The effects of Izh proteins on zinc homeostasis have been related either directly or indirectly to their effects on lipid metabolism [24].

The effects of steroid hormones in the development of the parasitic forms of pathogenic dimorphic fungi, drug resistance and susceptibility to infection, makes the identification of specific steroid receptors and steroid binding proteins of outmost importance in the treatment of fungal infections [reviewed in 25]. In Paracoccidioides brasiliensis the susceptibility to infection was observed to be dependent on gender, men being more susceptible than women, while in the case of Coccidioides immitis, pregnancy increases the risk of developing the disease [26]. In both of these cases, hormones were suggested as responsible for these differences. On the other hand, in vitro studies of the phase transition from mycelium to yeast in $P$. brasiliensis showed that the transition to the yeast form was inhibited in the presence of estrogen [25]. In Candida albicans, steroids were found to alter the response to antifungal drugs [25].

Nevertheless, the identification of progesterone membrane receptors in fungi has been elusive. As mentioned above, specific receptors for steroid hormones in pathogenic fungi have not been thoroughly studied and identified. Progesterone has been reported to bind to fungal membranes but the direct identification of specific progesterone receptors has not been reported until now. In Rhizopus, membrane ligand-binding assays suggest the presence of a progesterone receptor but that has not led to the identification of the specific receptor [27-30].

In this work we identified a homologue of the PAQR family as an interacting protein of the S. schenckii G protein alpha subunit, SSG2, using the yeast two-hybrid analysis. Using a yeast-based assay we determined that progesterone was the ligand of this S. schenckii PAQR (SsPAQR1). This assay was used because it is specific for PAQRs and was intended for the study of these receptors without the intervention of other possible progesterone binding proteins. The receptor was expressed in $S$. cerevisiae that has no other known progesterone receptor. We also report the effects of this agonist on the growth of the fungus from conidia and on the intracellular cyclic 3', 5' adenosine monophosphate (cAMP) levels in $S$. schenckii yeast cells at various time intervals following exposure to the hormone.

\section{Results}

\section{Yeast two-hybrid screening}

A yeast two-hybrid assay was done using the complete coding sequence of SSG-2 as bait and a S. schenckii yeast cells cDNA library. In this screening, a 483 bp insert from a blue colony growing in quadruple drop out (QDO) medium (SD/-Ade/-His/-Leu/-Trp/X- $\alpha$-gal) was sequenced and found to encode the last 38 amino acid of the C-terminal residues of a protein homologous to Izh3 from S. cerevisiae (GenBank no. NP_013123.1).

\section{Sequencing of the SsPAQR1 gene}

Figure 1 shows the cDNA and derived amino acid sequence of sspaqr1 gene obtained using $5^{\prime}$ RACE. This figure shows a $1981 \mathrm{bp}$ cDNA with an ORF of $1542 \mathrm{bp}$ 


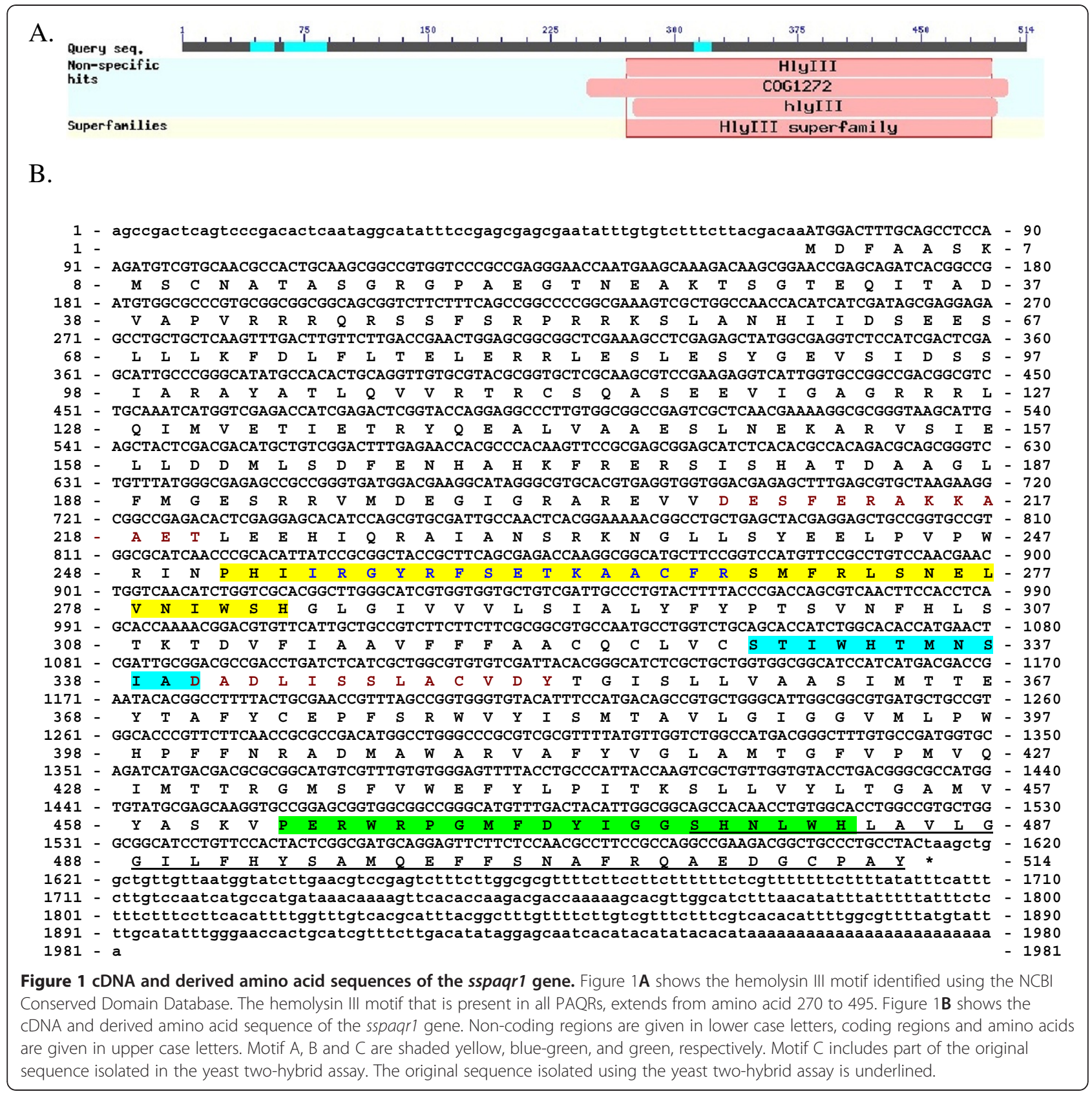

encoding a 514 amino acid protein with a calculated molecular weight of $57.8 \mathrm{kDa}$. The GenBank accession numbers for the cDNA and derived amino acid sequence, respectively are: EU439945.1 and ACA43006.1. The PANTHER Classification System identified this protein as a member of the PAQR family (PTHR20855: SF10) (residues 149-512) with an extremely significant E value of $3.8 \mathrm{e}^{-158}$ [31].

Figure 1 also shows the characteristic residues that identify the members of the Class II PAQR family of receptors. The Class II PAQR family (progesterone receptors) is characterized by the presence of 7 transmembrane domains, and three highly conserved amino acid motifs [13]. These include: motif A (shaded in yellow), consisting of the sequence $\mathrm{Nx}_{3} \mathrm{H}$ found $\mathrm{N}$-terminal to TM1; motif $\mathrm{B}$, consisting of the sequence $\mathrm{Sx}_{3} \mathrm{H}$ (shaded in blue-green) at the end of TM2 and an aspartic acid residue at the beginning of TM3, and motif $\mathrm{C}$ (shaded in green), consisting of the sequence, $\mathrm{Hx}_{3} \mathrm{H}$ in the loop region between TM6 and TM7 [7,13]. It is of interest to note that motif $\mathrm{C}$ includes part of the original sequence isolated in the yeast twohybrid assay; this sequence is underlined in Figure 1.

Figure 2 shows the results obtained when the SsPAQR1 sequence was analyzed for transmembrane 


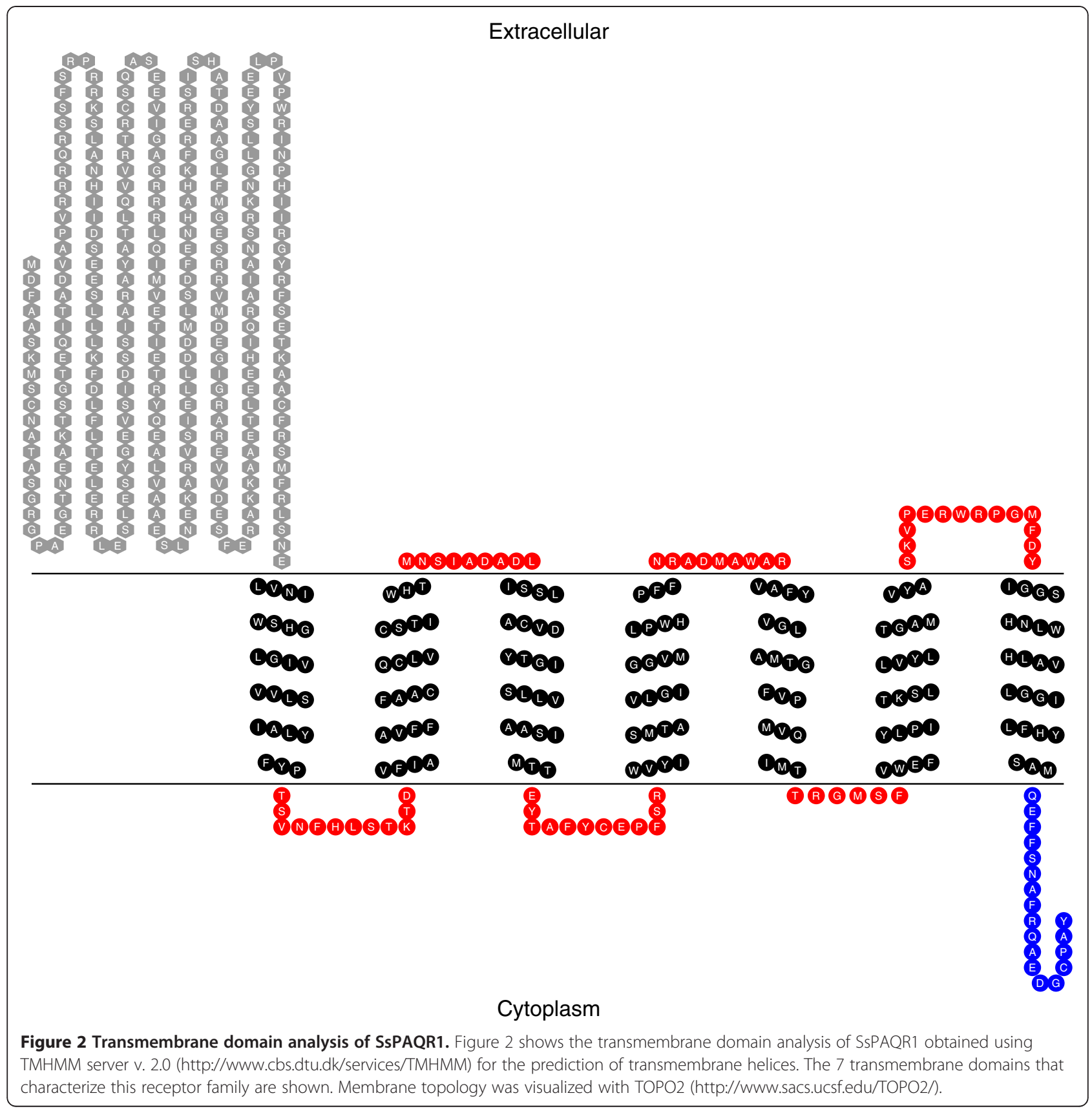

domains using the TMHMM server v. 2.0 and TOPO 2 [32]. This figure shows the 7 transmembrane domains that characterize these receptors. According to the TMHMM server, SOSUI server and PSIPRED Protein structure prediction server (MEMSAT-SVM) analyses [32-34], the N-terminal domain is extracellular and the C-terminal domain is intracellular as shown. PSORT II analysis identified the localization of this receptor in the plasma membrane with a $45 \%$ probability [35]. Signal peptide analysis using Predotar [36], TargetP [37] or MitoProt [35] showed that the SsPAQR1 has no mitochondrial targeting signal peptide at its $\mathrm{N}$-terminal as compared to PAQR 9, 10 and 11 that have mitochondrial localization signals. MEMSAT-SVM analysis identified a signal peptide comprising the region from amino acids 1 to 39 [34]. This signal sequence possibly allows its passage through the ER to its final destination.

A multiple sequence alignment of the derived amino acid sequence of SsPAQR1 to other fungal homologues and the human PAQR7 is included in Additional file 1. BLAST search for the predicted amino acid sequence identified this protein as 65 to $80 \%$ identical to other PAQRs of fungi such as: Neurospora crassa, Magnaporthea oryzae, Giberella zeae, among others. It is also 
shows that it is approximately $50 \%$ identical to S. cerevisiae Izh3 family channel protein.

\section{Co-immunoprecipitation (Co-IP) and western blots}

The SSG-2/SsPAQR1 interaction was corroborated using co-immunoprecipitation and Western Blot as shown in Figure 3. Lane 1 shows the band obtained using anticMyc antibody that recognizes SSG-2. This band is of the expected size $(58 \mathrm{kDa})$ considering that SSG-2 was expressed fused to the GAL-4 binding domain. Lane 2 shows the results obtained in the Western blot when the primary anti-cMyc antibody was not added (negative control). Lane 3 shows the band obtained using anti-HA antibody that recognizes the original SsPAQR1 fragment isolated from the yeast two-hybrid clone. This band is of the expected size $(22.4 \mathrm{kDa})$ considering that only the last 38 amino acids of the protein were present and that this fragment was fused to the GAL-4 activation domain. Lane 4 shows the results obtained in the Western blot when the primary anti-HA antibody was not added (negative control).

\section{Yeast-based assay}

To identify the agonist of the SsPAQR1, a yeast-based assay was used [13]. This assay is based on the fact that PAQRs expressed in yeasts, activate a signal transduction pathway that represses the expression of the FET3 gene. Yeast cells were co-transformed with plasmids, YEp353 (FET3-lacZ) and a plasmid containing the PAQR insert, either pYES2CT or pGREG536. The response of FET3 fused to the lacZ gene was used as a reporter for PAQR receptor activity. Figure 4A shows the effects of SsPAQR1 on FET3-lacZ when overexpressed in yeasts using the GAL1 promoter for randomly selected colonies. These results show that in the absence of agonist, SsPAQR1 did not significantly repressed FET3-lacZ using the Student's t-test ( $\mathrm{p}>0.05)$. Figure $4 \mathrm{~B}$, shows that when exposed to $1 \mathrm{mM}$ progesterone, transformed yeasts cells expressing SsPAQR1 elicited a significant repression of FET3-lacZ (Student's t-test, $\mathrm{p}<0.05)$ when compared to yeast cells transformed with the empty plasmid or the SsPAQR1-containing plasmid with added ethanol (controls). A small repression of FET3-lacZ was observed in yeasts transformed with the empty plasmid if progesterone was added; nevertheless, the level of repression of FET3-lacZ was significantly larger when yeast cells transformed with the plasmid expressing SsPAQR1 were treated with the ligand (Student's t-test, $\mathrm{p}>0.05$ ). This figure also shows the results obtained with PAQR 7 used as a positive control. PAQR 7 is a previously characterized progesterone receptor. This figure shows the combined data of the effects of progesterone on FET3-lacZ expression of 4 randomly picked colonies of cells transformed with the plasmid pGREG536 containing PAQR 7. The differences on FET3-lacZ expression were significant using the Student's t-test $(\mathrm{p}<0.05)$. Figure $4 \mathrm{C}$ and $4 \mathrm{D}$ show no significant repression of FET3-lacZ when thaumatin (50 $\mu \mathrm{M})$ or adiponectin $(0.1 \mu \mathrm{M})$ were used as ligands for the same 4 colonies transformed with the plasmid expressing SsPAQR1 when compared to the controls (Student's t-test, $\mathrm{p}<0.05$ ).

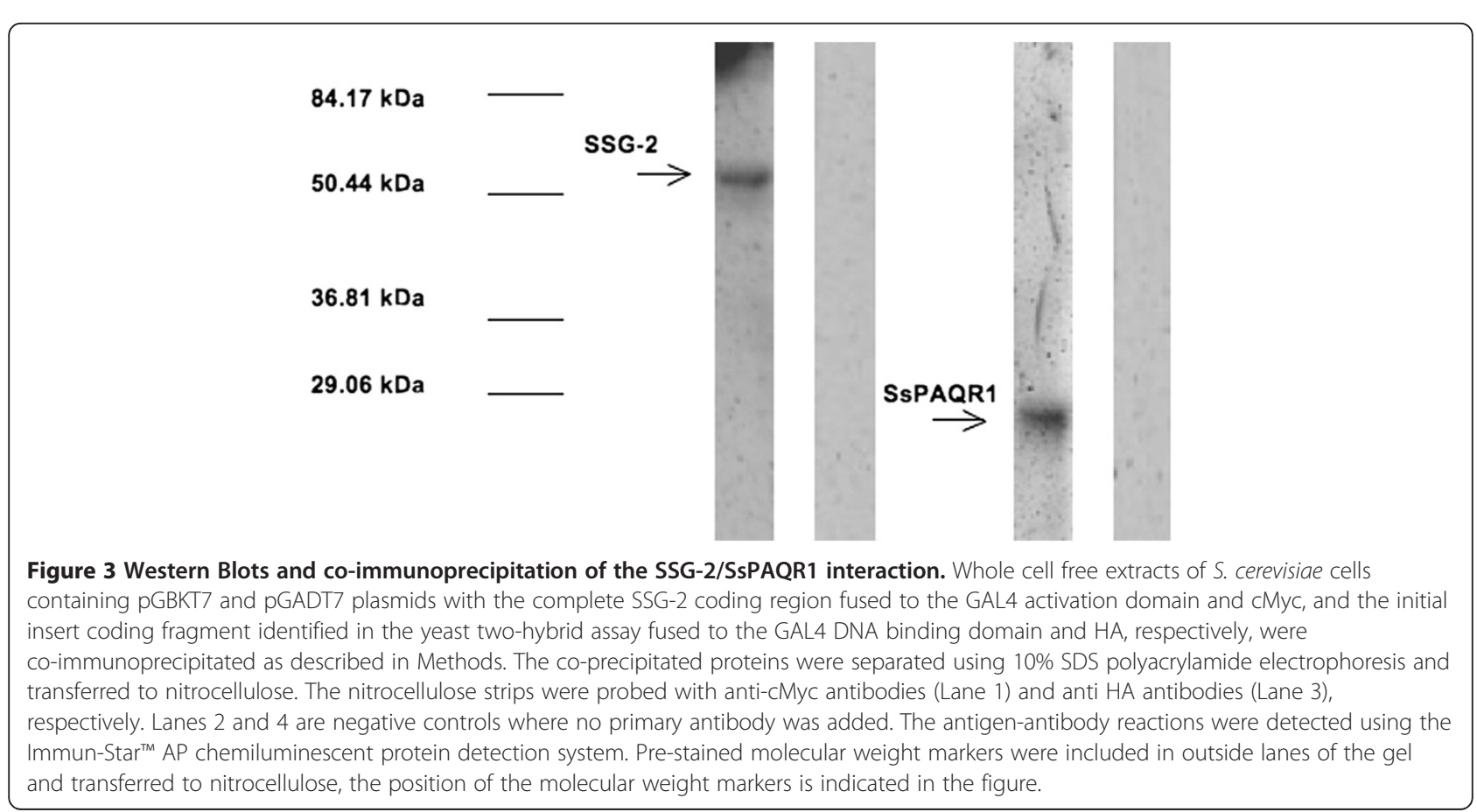




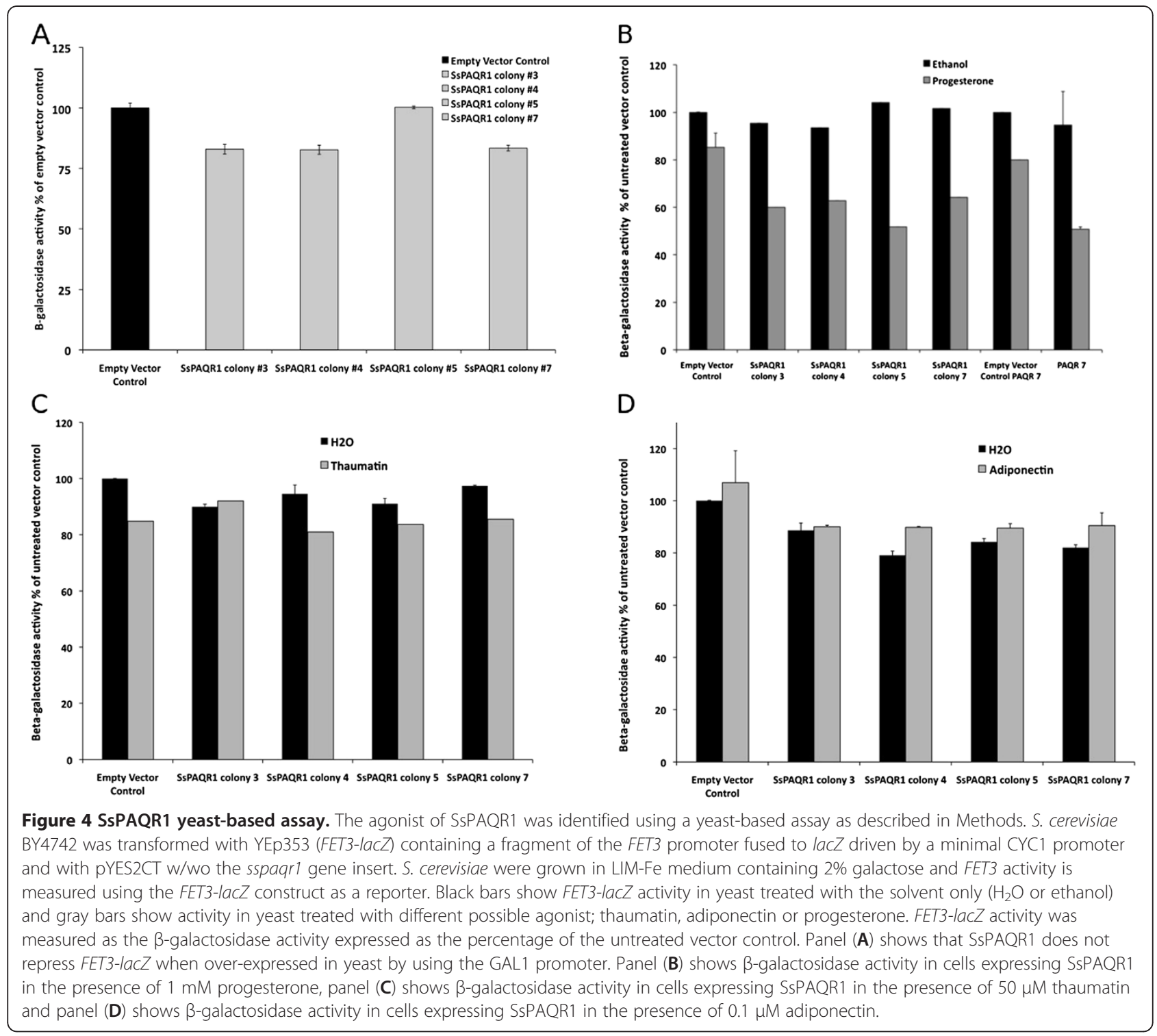

\section{Intracellular cAMP levels in S. schenckii treated with progesterone}

Figure 5 shows the cAMP levels of S. schenckii yeast cells exposed to progesterone $0.5 \mathrm{mM}$ for different time intervals $(1,10,30,60$, and 300 minutes) before harvesting for CAMP determinations. This figure shows that there was an immediate significant increase in the levels of cAMP in cells treated with progesterone within $1 \mathrm{~min}$ after the addition of progesterone when compared to the controls (Student's t-test, $\mathrm{p}>0.05$ ). A significant decrease in cAMP levels was observed when cells were treated with progesterone for $5 \mathrm{~h}$. Analysis of Variance between groups, done using Bonferroni Test for differences between means revealed that there were no differences in the cAMP levels between samples taken at 1, 10, 30 and 60 minutes following exposure to progesterone but all were significantly different when compared to that obtained after $300 \mathrm{~min}$ of exposure.

\section{Effects of progesterone on growth of S. schenckii}

Progesterone inhibited growth of $S$. schenckii conidia in Medium $\mathrm{M}$ agar plates. Table 1 shows the colony diameter of conidia incubated at $25^{\circ} \mathrm{C}$ and $35^{\circ} \mathrm{C}$ in medium $\mathrm{M}$ agar plates for 20 days at different concentrations of added progesterone. This table shows that conidia did not germinate at concentrations of progesterone of 0.05 $\mathrm{mM}$ or above at $35^{\circ} \mathrm{C}$. These same conidia inoculated in medium $\mathrm{M}$ plates with different concentrations of added progesterone and incubated at $25^{\circ} \mathrm{C}$ grew at all concentrations of the hormone. Nevertheless the growth was significantly smaller at concentrations of progesterone 


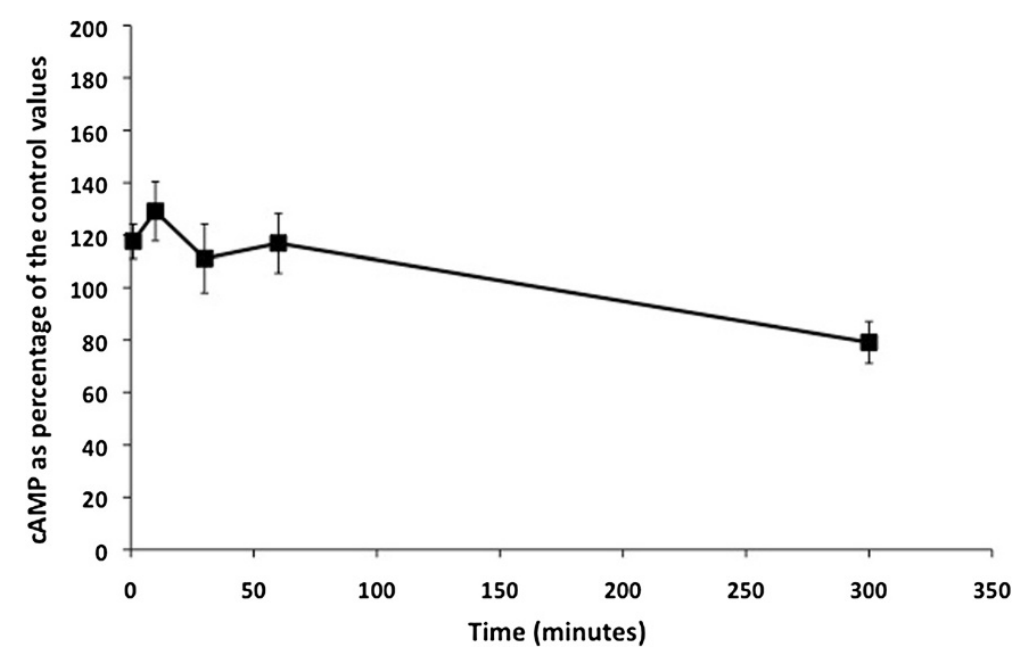

Figure 5 Effects of progesterone on intracellular cAMP in S. schenckii. This figure shows the CAMP response curve after the exposure of S. schenckii yeast cells to progesterone for different time intervals. The cells were grown in a variation of medium $\mathrm{M}$ for 4 days and aliquots were removed and exposed to progesterone as described in Methods. The intracellular levels of CAMP were measured as described in Methods using the cAMP Direct Immunoassay kit (Calbiochem, La Jolla, CA, USA). The CAMP concentration was determined for at least 7 independent experiments and the values expressed as percentage of the untreated controls (ethanol only) \pm the standard error of the mean. Significance of the data was determined using the Student's $T$ test and at a $p<0.05$. Analysis of Variance between groups was done using Bonferroni Test for differences between means.

$0.05 \mathrm{mM}$ or above when measured as the diameter of the colony (Student's t-test, $\mathrm{p}<0.05$ ).

\section{Discussion}

A seemingly universal new family of receptors, the PAQRs, that originated from ancestral bacterial hemolysin encoding genes has been described in eukaryotes [7].

Table 1 Effects of Progesterone on S. schenckii yeast and mycelium growth from conidia

\begin{tabular}{|c|c|c|}
\hline $\begin{array}{l}\text { Progesterone } \\
\text { concentration } \\
(\mathrm{mM})\end{array}$ & $\begin{array}{l}\text { Average diameter } \\
\text { of colonies incubated } \\
\text { at } 25^{\circ} \mathrm{C}(\mathrm{cm})^{a, b, c}\end{array}$ & $\begin{array}{l}\text { Average diameter } \\
\text { of colonies incubated } \\
\text { at } 35^{\circ} \mathrm{C}(\mathrm{cm})^{a, b, c}\end{array}$ \\
\hline 0 & $2.40 \pm 0.18$ & $1.47 \pm 0.13$ \\
\hline 0.010 & $2.35 \pm 0.10$ & $1.33 \pm 0.11$ \\
\hline 0.050 & $2.10 \pm 0.11^{*}$ & no growth \\
\hline 0.125 & $1.78 \pm 0.07^{*}$ & no growth \\
\hline 0.250 & $1.47 \pm 0.16^{*}$ & no growth \\
\hline 0.500 & $1.22 \pm 0.11^{*}$ & no growth \\
\hline
\end{tabular}

This table shows the colony diameter attained after conidia were inoculated at $25^{\circ} \mathrm{C}$ and $35^{\circ} \mathrm{C}$ in a modification of medium $\mathrm{M}$ agar plates with different concentrations of added progesterone. No growth was observed at concentrations of progesterone of $0.05 \mathrm{mM}$ or above, at $35^{\circ} \mathrm{C}$ while conidia incubated at $25^{\circ} \mathrm{C}$ germinated and showed growth at all concentrations of progesterone tested. The data represents the average diameter \pm one std deviation of 6 independent experiments.

${ }^{a}$ The cultures were incubated at the desired temperature for 20 days.

${ }^{b}$ All cultures were inoculated with $5 \mu \mathrm{l}$ of a suspension containing $10^{6} / \mu \mathrm{l}$ conidia.

c The values given are the average of 6 independent determinations.

* The values marked with an asterisk are significantly different from the values where no progesterone was added to the medium.
Much controversy surrounds these receptors specifically, their membrane topology and the possibility of being coupled to $G$ protein signalling pathways [17]. Nevertheless, the nature of the ligands bound by a particular receptor has been solved for most PAQRs. They have been observed to bind either the peptide hormone adiponectin or the steroid hormone progesterone [38,39]. This brings up another consideration; should the adiponectin and progesterone receptors be considered members of the same family of receptors? The fact that the nature of the ligands are so different, together with the differences observed in membrane topology between the Class I (adiponectin receptors) and Class II (progesterone receptors) suggest inherent difference between the two classes. Class I receptors have been predicted to have the $\mathrm{N}$-terminal in the interior of the cell while Class II receptors have the usual GPCR topology of the N-terminal outside of the cell and the C-terminal inside the cell $[8,20]$. Due to the predicted membrane topology of the progesterone receptors, it is suggests that they might be a new class of GPCRs. In this paper we report a new member of the Class II PAQRs and address the issues regarding membrane topology, ligand binding and its relationship to the S. schenckii G alpha subunit SSG-2, in an effort to characterize the SsPAQR1.

The fact that SsPAQR1 was identified in a Y2H assay with a $\mathrm{G}$ protein alpha subunit as bait, offers for the first time direct evidence of the association of these receptors to the heterotrimeric $\mathrm{G}$ protein signalling pathways. This association was verified using Co-IP. Indirect evidence of 
the association of progesterone PAQRs to $G$ proteins has been reported by other investigators. One of these instances involves fish oocyte maturation where response to a novel progesterone hormone was associated to a pertussis-sensitive Goi subunit pathway $[6,11,40]$.

Transmembrane analysis of the SsPAQR1 described here predicts that this protein has the 7 transmembrane domains characteristic of GPCRs like other progesterone binding members of the PAQR family. The bioinformatic analyses described above (TMHMM, SOUSI and MEMSAT-SVM) predicted that the $\mathrm{N}$-terminal region is localized outside the plasma membrane while the $\mathrm{C}$-terminal region is intracellular. This orientation has also been observed in progestin receptors, PAQR6 and $\mathrm{mPRa}$ [6]. In the case of the adiponectin members of the PAQR family such as the human adiponectin receptor 2 and 3, the orientation seems to be the opposite, as stated previously $[12,41]$.

Bioinformatic analyses also show that SsPAQR1 and its fungal homologues from $M$. oryzae, $T$. reesei, $N$. crassa and $P$. anserina, among others belong to the PAQR receptor family. These homologues exhibit approximately 65 to $80 \%$ identity to SsPAQR1. The transmembrane domain analyses of some of these fungal homologues showed that most have the 7 transmembrane domains characteristic of the GPCRs. TMHMM analysis also shows that they have the traditional orientation of an external N-terminal domain and an internal C-terminal domain as SsPAQR1, except in the case of Izh3 where the $\mathrm{N}$-terminal is inside and the $\mathrm{C}$-terminal is outside (Additional file 2). It is also of interest to note that in many filamentous and dimorphic fungi where whole genomes have been sequenced, the SsPAQR1 homologues encode proteins of approximately 500 amino acids in addition to at least one more Izh homologue of smaller size (approximately 300 amino acids).

Steroid binding proteins have been described for various yeasts [42]. Many studies have predicted the existence of a progesterone receptor in the membrane of filamentous fungi such as Rhizopus nigricans [27-30] but the molecular basis of steroid signalling in fungi remains unresolved $[43,44]$. Progesterone has been reported to bind to enriched plasma membrane fractions of $R$. nigricans with high affinity and this hormone has been reported to induce an activation of $G$ proteins that decreases in the presence of cholera toxin [29]. Nevertheless, to date no progesterone receptor has been directly identified in this or any other fungi. This work identified a membrane progesterone receptor for the first time in fungi. Progesterone was identified as the ligand corresponding to SsPAQR1 using the yeast-based assay $[23,45]$. This assay was used previously to identify the ligands of human PAQRs heterologously expressed in S. cerevisae [46]. This assay is specific for PAQRs and was intended for the study of these receptors without the intervention of other possible progesterone binding protein. Using this assay, SsPAQR1 was expressed in $S$. cerevisiae and progesterone was identified as the ligand for SsPAQR1. Yeasts carrying the empty expression vector showed that progesterone did not affect FET3, showing that the effect was not due to a nonspecific effect of progestrone on S. cerevisiae. Progesterone responsiveness was only observed if SsPAQR1 was being expressed. These results put an end to the uncertainty regarding the presence of a membrane progesterone receptor in fungi.

However, the question as to why fungi have a steroid hormone receptor remains unanswered. The effects of progesterone and other steroids on fungi have not been fully documented. In Candida albicans the response to steroid hormones leads to the activation of transcription of genes encoding the ATP-binding cassette of drug efflux pumps [47]. In S. cerevisiae exposure to progesterone results in the up-regulation of stress response genes such as those involved in transport, oxidative stress response, growth, cell division and cell wall biogenesis, among other [43].

In the filamentous fungi, most of the information regarding progesterone and fungi is related to bioconversion of the different steroid metabolites by fungi. Recently, a progesterone-hydroxylating enzyme system was studied and found to be dependent on the $G$ protein beta subunit and cAMP in Fusarium oxysporum [48]. The authors proposed that progesterone is toxic to this fungus and that by the induction of the enzymes involved in the hydroxylation of progesterone, the fungus is able to reduce the toxicity associated with the hormone. This transformation results in a more soluble compound that can be excreted to the medium.

The toxicity of progesterone results in an inhibition of growth in $R$. nigricans [49]. This inhibition of growth was explained as resulting from a decrease in cAMP caused by progesterone. In this work we also report an inhibition of growth of both the mycelium and yeast forms of the fungus in the presence of progesterone, the yeast form being the most affected. Nevertheless, we could not correlate this inhibition of growth to a decrease in cAMP concentrations.

Another major area of concern regarding progesterone PAQRs is the determination of the specific signal generated upon the interaction of the receptor with its ligand. Different theories have suggested that cAMP and/or calcium could be involved. Nevertheless, even in situations where adenylate cyclase has been identified as a target of the possible effects of progesterone, there is still disagreement if the hormone causes a decrease or an increase in cAMP, and the time considered reasonable for the effect on this cyclic nucleotide to be observed $[50,51]$. The addition of progesterone to S. schenckii 
yeast cells prior to harvesting for cAMP determinations showed that the levels of intracellular cAMP increased during the first minute after exposure to the ligand and decreased significantly after five hours incubation with the hormone. The increase in the cytosolic concentration of cAMP could be the result of the interaction of the ligand and the receptor resulting in the activation of SSG-2 that in turn triggers the cascade of events leading to an increase in cAMP. The response to the ligand in steroid membrane receptors has been identified as occurring in 1 to $5 \mathrm{~min}$ in the case of sperm motility to up to $6-18 \mathrm{~h}$ in the case of oocyte maturation experiments [50].

The work reported here identifies the presence of a progesterone receptor in S. schenckii for the first time and establishes the presence of homologous of this receptor in other fungi as well. Other authors who studied the response of fungi to progesterone have proposed the existence of this receptor. Although the question still remains regarding the benefit of having such receptors in fungal cells remains open, one could argue that fungi are in contact with plant and other fungal steroids in their environment and that they have the capacity to transform these molecules to suite their needs [52].

\section{Conclusions}

The information available concerning members of the PAQR receptor family is limited and controversial. Several investigators have proposed the existence of a progesterone receptor in fungal membranes. In this work we identified for the first time a progesterone receptor belonging to the PAQR Class II family in S. schenckii. A yeast-based assay similar to the one used to identify the ligand for the human PAQRs, was used to identify the ligand of this receptor. This study constitutes the first evidence of the interaction of a fungal $G \alpha$ subunit with a member of the PAQR family using both yeast two-hybrid assay and coimmunoprecipitation and Western Blot. The association of a $G$ protein alpha subunits with SsPAQR1 suggests that these receptors are G protein coupled. As with many G protein coupled receptors, the hormone affects the growth of the fungus possibly by a mechanism involving cAMP. The progesterone receptor that we have identified in $S$. schenckii, brings to a close the search for a membrane progesterone receptor in fungi.

\section{Methods}

\section{Strains and culture conditions}

S. schenckii (ATCC 58251) was used for all experiments. The yeast form of this fungus was obtained as described previously [53]. S. cerevisiae strains AH109 and Y187 were used for the yeast two-hybrid screening and were supplied with the MATCHMAKER Two-Hybrid System (Clontech Laboratories Inc., Palo Alto, CA). S. cerevisiae strain BY4742 for the yeast-based ligand-binding assay was obtained from Dr. Thomas J. Lyons, from the Foundation for Applied Molecular Evolution (Gainesville, FL).

\section{Nucleic acids isolation}

DNA and RNA were obtained from S. schenckii yeast cells as described previously [54]. Poly $\mathrm{A}^{+}$RNA was obtained from total RNA using the mRNA Purification Kit from Amersham Biosciences (Piscataway, NJ, USA) and used as template for cDNA synthesis.

\section{Yeast two-hybrid}

MATCHMAKER Two-Hybrid System was used for the yeast two-hybrid assay (Clontech Laboratories Inc., Palo Alto, CA) using all 3 different reporter genes for the confirmation for truly interacting proteins as described previously [55]. For the construction of the bait plasmid, ssg2 cDNA was obtained from poly $\mathrm{A}^{+}$RNA, transcribed and amplified by RT-PCR using the Ready-to-Go ${ }^{\text {to }}$ Beads (Amersham Biosciences) as described [55], cloned and used to transform competent $S$. cerevisiae yeast cells (Y187). Competent S. cerevisiae yeast cells were transformed using the YEASTMAKER ${ }^{\mathrm{mm}}$ Yeast Transformation System 2 from Clontech (BD Biosciences, Clontech Laboratories Inc.).

Poly $\mathrm{A}^{+}$RNA was isolated form total RNA extracted from logarithmically growing S. schenckii yeast cells. Double stranded cDNA was synthesized from RNA using SMART ${ }^{\mathrm{Tu}}$ Technology Kit (Clontech Laboratories Inc.). The cDNAs were amplified using Long Distance PCR and size selected using the BD CHROMASPIN $^{\mathrm{ma}}+\mathrm{TE}-400$ columns (Clontech Laboratories Inc.) [55].

S. cerevisiae yeast cells AH109 transformed with

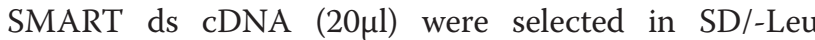
plates, harvested and used for mating with the bait containing $S$. cerevisiae strain Y187. Mating of $S$. cerevisiae yeast cells strains Y187 (Mat- $\alpha$ ) and AH109 (Mat-a) was done according to the manufacturer's instructions. The expression of three reporter ADE2, HIS3 and MEL1 genes in the diploids was used as confirmation for true interacting proteins. Diploids expressing interacting proteins were selected as described previously [55]. Colony PCR was used to corroborate the presence of both plasmids in the diploid cells using the T7/3/BD sequencing primer pair for the pGBKT7/ssg- 2 plasmid and the T7/3'AD primer pair for the pGADT7-Rec library plasmid. PCR was used to amplify the inserts in the isolated plasmid with the T7 Sequencing Primer $/ 3^{\prime} \mathrm{AD}$ sequencing primer pair provided with MATCHMAKER TwoHybrid System, and the PCR product was cloned and sequenced as described previously [55]. 


\section{Co-immunoprecipitation (Co-IP)}

S. cerevisiae diploids obtained in the yeast two-hybrid assay were grown in $125 \mathrm{ml}$ flasks containing $25 \mathrm{ml}$ of QDO for 16h, harvested by centrifugation and resuspended in $8 \mathrm{ml}$ containing phosphate buffer saline $(800 \mu \mathrm{l})$ with phosphatase $(400 \mu \mathrm{l})$, deacetylase $(80 \mu \mathrm{l})$ and protease inhibitors $(50 \mu \mathrm{l})$, and PMSF $(50 \mu \mathrm{l})$. The cells were frozen in liquid nitrogen in a porcelain mortar, glass beads added and the cells broken as described previously [56]. The cell extract was centrifuged and the supernatant used for Co-IP using the Immunoprecipitation Starter Pack (GE Healthcare, Bio-Sciences AB, Bjorkgatan, Sweden) as described by the manufacturer. Briefly, $500 \mu \mathrm{l}$ of the cell extract were combined with 1$5 \mu \mathrm{g}$ of the anti-cMyc antibody (Clontech, Corp.) and incubated at $4^{\circ} \mathrm{C}$ for $4 \mathrm{~h}$, followed by the addition of protein $\mathrm{G}$ beads and incubated at $4^{\circ} \mathrm{C}$ overnight in a rotary shaker. The suspension was centrifuged and the supernatant discarded, $500 \mu \mathrm{l}$ of the wash buffer added followed by re-centrifugation. This was repeated 4 times. The pellet was resuspended in Laemmeli buffer $(20 \mu \mathrm{l})$ and heated for $5 \mathrm{~min}$ at $95^{\circ} \mathrm{C}$, centrifuged and the supernatant used for $10 \%$ SDS PAGE at 110V/1 h.

\section{Western blots}

Western blots were done as described by us previously [56]. The proteins were separated by electrophoresis and transferred to nitrocellulose membranes using the BioRad Trans Blot System ${ }^{\circledR}$ for $1 \mathrm{~h}$ at 20 volts. After transfer, the nitrocellulose strips were blocked with $3 \%$ gelatin in TTBS $(20 \mathrm{mM}$ Tris, $500 \mathrm{mM} \mathrm{NaCl}, 0.05 \%$ Tween-20, pH 7.5) at room temperature for 30-60 min. The strips were washed for 5-10 min with TTBS. The TTBS was removed and the strips incubated overnight in the antibody solution containing $20 \mu \mathrm{g}$ of antibody anti-cMyc or anti-HA (Clontech, Corp.). Controls where the primary antibody was not added were included. The antigen-antibody reaction was detected using the Immun-Star $^{\text {Tux }}$ AP chemiluminescent protein detection system from BioRad Corporation (Hercules, CA, USA) as described by the manufacturer.

\section{Sequencing of the sspaqr 1 gene \\ Rapid amplification of CDNA ends (RACE)}

The $5^{\prime}$ end of the sspaqr1 gene homologue was obtained using RLM-RACE (Applied Biosystems, Foster City, CA, USA) with $S$. schenckii cDNA as template. All RACE reactions were carried out in the ABI PCR System 2720 (Applied Biosystems). The touchdown PCR and nested PCR parameters used for the initial RACE reactions were the same as described previously [55]. Nested primers were designed to improve the original amplification reactions. Bands from the $5 /$ nested PCR were excised from the gel and cloned as described previously [54]. Primers for RACE were designed based on the sequence obtained from the yeast two-hybrid assay. The touchdown and nested primer used to complete the cDNA secuences of sspaqr1 were: EFFSNAFRD-GSP (rev) 5 ctggcggaaggcgttggagaagaactc $3^{\prime}$, VLGGTLFHY-NGSP (rev) $5^{\prime}$ agtagtggaacaggatgccgcccagcac $3^{\prime}$, VFFLLFSRFF-GSPP2 (rev) $5^{\prime}$ aaaacgagaaaaaagaaggaa gaaaac $3^{\prime}$, EFY-GSP (rev) $5^{\prime}$ acttggtaatgggcaggtaaaactc $3^{\prime}$, VAFYV-NGSP (rev) $5^{\prime}$ ggccagaccaacataaaacgcgacg $3^{\prime}$, MTG-GSP2 (rev) $5^{\prime}$ caccatcggcacaaagcccgtcatg $3^{\prime}$, STIWGSP1 (rev) $5^{\prime}$ cgagttcatggtgtgccagatggtgct $3^{\prime}$, VFVA-GSP2 (rev) $5^{\prime}$ aagaagaagacggcagcaacgaacacg $3^{\prime}$, YGE-GSP (rev) $5^{\prime}$ tcgagtcgatggagacctcgccata $3^{\prime}$, FDL-GSP2 (rev) $5^{\prime}$ ccagttcggtcaagaacaagtcaaa $3^{\prime}$.

The complete cDNA coding sequence of the sspaqr1 gene was obtained using reverse transcriptase polymerase chain reaction (RTPCR). For RTPCR, RNA was extracted as described previously [54]. The cDNA was obtained using the RETROscript "First Strand Synthesis kit (Ambion, Applied Biosystems, Foster City, CA, USA) and used as template. : VLCLAYD(fw)/GGCDWYL(rev) primer pair. The sequence of these primers were the following: 5/ tatttgtgtctttcttac 3/ and 5/ ataccattaacaacagcc 3 , respectively. The following PCR parameters were used: an initial denaturation step at $94^{\circ} \mathrm{C}$ for $30 \mathrm{sec}$, followed by 25 cycles of denaturation at $94^{\circ} \mathrm{C}$ for $5 \mathrm{sec}$, annealing at $40^{\circ} \mathrm{C}$ for $10 \mathrm{sec}$, and extension at $72^{\circ} \mathrm{C}$ for 2 min. The RTPCR products were cloned as described previously [54] and the inserts sequenced using commercial sequencing services from Davis Sequencing (Davis, CA, USA).

\section{Bioinformatics sequence analysis}

The theoretical molecular weight of SsPAQR1 was calculated using the on-line ExPASy tool (http://expasy.org/tools/ pi_tool.html). The protein classification was performed using the PANTHER Gene and Protein Classification System (http://www.PANTHERdb.org) [31]. On-line database search was performed with the BLAST algorithm (http://www.ncbi. nlm.nih.gov/BLAST/) with a cutoff of $10^{-7}$, a low complexity filter and the BLOSUM 62 matrix [57]. Transmembrane domains were identified using TMHMM Server v. 2.0 (http://www.cbs.dtu.dk/services/TMHMM) [32] and visualized with TOPO2 (http://www.sacs.ucsf.edu/TOPO2/). SOSUI server (http://bp.nuap.nagoya-u.ac.jp/sosui/sosuiframe0E.html) and PSIPRED Protein Prediction server, MEMSAT-SVM (http://bioinf.cs.ucl.ac.uk/psipred/) were also used to identify transmembrane domains [33,34,58]. Cellular localization of the SsPAQR1 was done using PSORT II Server (http://PSORT.ims.u-tokyo.ac.jp/) [35] and for the identification of mitochondrial signal sequence Predotar (http:// urgi.versailles.inra.fr/predotar/predotar.html) [36], TargetP 1.1 server (http://www.cbs.dtu.dk/services/TargetP) [37] and MitoProt (http://ihg.gsf.de/ihg/mitoprot.html) [59] servers were used. Multiple sequence alignments were built using 
MCOFFEE (http://igs-server-cnrs-mrs.fr/tcoffee/tcoffee cgi/index.cgi) [60]. The alignment in Additional file 1 was visualized using GeneDoc (http://www.psc.edu/ biomed/ genedoc). The accession numbers of the sequences used for the multiple sequence alignment of $\mathrm{G}$ protein subunits were: S. schenckii, ACA43006.1; M. oryzae, XP_362234.1; Trichoderma reesei, EGR51560.1; N. crassa, XP_965338.1; Chaetomium globosum, XP_001221101.1; F. oxysporum, EGU81989.1; Podospora anserina, XP_001912493.1; Gibberella zeae, XP_381240.1; Paracoccidioides brasiliensis, EEH45107.1; Aspergillus nidulans, EAA62332.1; S. cerevisiae, (Izh3p), NP_013123.1 and Ajellomyces capsulatus, EER42609.1.

\section{Yeast-based assay}

$S$. cerevisiae strain BY4742 cells (MAT $\alpha$ his $3 \Delta 1$ leu $2 \Delta 0$ lys $2 \Delta 0$ ura3 $\Delta 0$ ) co-transformed with plasmids, YEp353 (FET3-lacZ) and pYES2CT (1 $\mu$ g each) with the S.c. EasyComp ${ }^{\text {mm }}$ Transformation Kit (Invitrogen Corp. Carlsbad, CA, USA) was used for the ligand-binding assay. YEp353 (FET3-lacZ) contains a fragment of the FET3 promoter that includes the iron response element fused to lacZ driven by a minimal CYC1 promoter. The complete coding sequence of sspaqr1 gene was cloned into pYES2CT allowing galactose-inducible SsPAQR1 expression via GAL1 promoter. The YEp353 (FET3-lacZ) and pGREG536 w/wo the PAQR7 insert were generously provided by Dr. Thomas J. Lyons from the Foundation for Applied Molecular Evolution. Transformants were selected in SD (-leu/-ura). For the receptor activity assay, the transformants were grown overnight in synthetic defined (SD) media without the appropriate amino acids $\left(\mathrm{OD}_{600}, 1-1.5\right)$. The overnight culture was used to inoculate $5 \mathrm{ml}$ of LIM-Gal medium (low iron media, LIM-FE, with $2 \%$ galactose as carbon source) to induce full expression of the PAQR gene driven by the GAL1 promoter and incubated at $30^{\circ} \mathrm{C}$ with shaking. Five hundred $\mu \mathrm{l}$ of the cells were added to $4.5 \mathrm{ml}$ LIM-GAL medium with the added ligand $(50.0 \mu \mathrm{M}$ thaumatin; $0.1 \mu \mathrm{M}$ adiponectin; $1.0 \mathrm{mM}$ progesterone) (Sigma-Aldrich, St. Louis, MO, USA and Phoenix Pharmaceuticals, Phoenix, AZ, USA) or the solvent alone (controls) and incubated overnight at $30^{\circ} \mathrm{C}$ with shaking. The cells were centrifuged and resuspended in $250 \mu \mathrm{l}$ of breaking buffer, $\mathrm{OD}_{600}$ of the suspension was determined and glass beads were added together with $12.5 \mu \mathrm{l}$ of PMSF. The cells were vortexed at least 6 times with chilling period in between vortexing periods. More breaking buffer was added at the end $(250 \mu \mathrm{l})$, mixing well and the extract recovered. Ten $\mu \mathrm{l}$ of this extract were added to $990 \mu \mathrm{l}$ of $\mathrm{Z}$ buffer (60 mM NaH${ }_{2} \mathrm{PO}_{4}, 40 \mathrm{mM} \mathrm{Na} \mathrm{HPO}_{4}, 10 \mathrm{mM} \mathrm{KCl}, 1$ $\mathrm{mM} \mathrm{MgSO} 4, \mathrm{pH} 7.0$ ) and the mixture incubated at $28^{\circ} \mathrm{C}$ for $5 \mathrm{~min}$. The reaction was initiated by adding $200 \mu \mathrm{l}$ of a stock solution of ONPG $(4 \mathrm{mg} / \mathrm{ml})$ and the mixture incubated for $10 \mathrm{~min}$ at $28^{\circ} \mathrm{C}$. The reaction was terminated by adding $500 \mu \mathrm{l}$ of $1 \mathrm{mM} \mathrm{Na}_{2} \mathrm{CO}_{3}$ and the optical density recorded at $420 \mathrm{~nm}$. For all experiment, equal volumes of the appropriate solvent were added to untreated cells as control for vehicle effects. The data shows the individual results obtained with 4 different colonies transformed with the above-mentioned plasmids. The data for PAQR 7 represents the combined data of 4 different colonies.

\section{Cyclic 3', 5'-adenosine monophosphate assay (cAMP)}

S. schenckii yeast cells were grown from conidia for 4 days at $35^{\circ} \mathrm{C}$ as described previously [53]. Ten $\mu$ l of ethanol or progesterone $(0.5 \mathrm{mM})$ were added to $1 \mathrm{ml}$ aliquots $\left(10^{6}\right.$ cells $\left./ \mathrm{ml}\right)$ of the culture for a predetermined period of time $(1,10,30,60$ and $300 \mathrm{~min})$. The cells were centrifuged and $0.01 \mathrm{mM} \mathrm{HCl}(400 \mu \mathrm{l})$ was added to the cells together with glass beads. The cells were vortexed for $1 \mathrm{~min}$ and frozen at $-80^{\circ} \mathrm{C} 3$ times, followed by centrifugation. One hundred $\mu \mathrm{l}$ of this suspension was assayed colorimetrically for cAMP using the cAMP Direct Immunoassay kit (Calbiochem, La Jolla, CA, USA). The cAMP concentration was determined for at least 7 independent experiments and the values expressed as percentage of the untreated controls (ethanol only).

\section{Effects of progesterone on growth of S. schenckii}

Conidia were obtained from 5 day old mycelial slants growing in Saboureau dextrose agar by gentle resuspension with sterile distilled water. Cultures were inoculated in medium $\mathrm{M}$ agar plates with $5 \mu \mathrm{l}$ of a suspension containing $10^{6} / \mu \mathrm{l}$ conidia. Different concentrations of progesterone, ranging from 0.00 to $0.5 \mathrm{mM}$ were added to the medium. Cultures were incubated at the desired temperature $\left(25^{\circ} \mathrm{C}\right.$ or $\left.35^{\circ} \mathrm{C}\right)$ for 20 days. The diameter of the colonies was measured at the end of this time period. The values given are the average of 6 independent determinations \pm a standard deviation.

\section{Statistical analysis}

Data was analysed using Student's t-test. A p-value of less than 0.05 was used to determine statistical significance. For the time series of the cAMP assay, an analysis of variance with repeated measures using a post-hoc Bonferroni test was used to determine statistical significance.

\section{Additional files}

Additional file 1: Amino acid sequence alignments of SsPAQR1 to other fungal protein homologues. The predicted amino acid sequence of S. schenckii SSPAQR1 and other fungal homologues proteins were aligned using MCoffee. In the alignment, black shading with white letters indicates 100\% identity, gray shading with white letters indicates 75-99\% identity; gray shading with black letters indicates $50-74 \%$ identity. Blue lines indicate the transmembrane domains of the SsPAQR1. 
Additional file 2: TMHMM analysis of SSPAQR1 fungal protein homologues. The TMHMM analysis was done using sequences retrieved from GenBank by means of BLAST. Sequences A to J correspond to: A. capsulatus, A. nidulans, C. globosum, F. oxysporum, G. zeae, M. oryzae, N. crassa, P. anserina, P. brasiliensis and S. cerevisiae (Izh3), respectively.

\section{Competing interests}

All of the authors state that they have not received any fees, funding or salary, nor hold stocks from any organization that in any way will gain or loose financially from the publication of this paper. No authors are at the present applying for any patent related to the content of this paper.

\section{Authors' contributions}

WGV did all the studies described in this manuscript including the yeast two-hybrid assay that identified SSPAQR1 as a SSG-2 interacting protein. She also did the Co-IP experiments, ligand assays, CAMP determinations and the sequencing of the SSPAQR1. This work was done as part of her research for the PhD degree. RGM participated and supervised the bioinformatic study of the proteins and statistical analysis calculations. NRV designed the study, drafted the manuscript, participated in sequence alignments, data and statistical calculations, and domain characterizations. All authors read and approved the final manuscript.

\section{Acknowledgements}

This investigation was supported by the Dean of Medicine University of Puerto Rico, Medical Sciences Campus, UPR and was partially supported by the National Institute of General Medicine, Minority Biomedical Research Support Grant 3S06-GM-008224 and the MBRS-RISE Program Grant R25GM061838. The NIH-RCMI grant 2G12RR003051-26 covered the expenses of WGV visit to Dr. Thomas Lyons laboratory. RGM acknowledges funding through NIH NIGMS grant T36GM008789-05 and acknowledges the use of the Pittsburgh Supercomputing Center National Resource for Biomedical Supercomputing resources funded through NIH NCRR grant 2 P41 RR06009-16A1. The authors want to acknowledge the contribution of Dr. Thomas J. Lyons in providing his expertise and training in the yeast-based assay to WGV.

\section{Author details}

${ }^{1}$ Department of Microbiology and Medical Zoology, Medical Sciences Campus, University of Puerto Rico, PO Box 365067, San Juan PR 00936-5067, USA. ${ }^{2}$ Department of Radiological Sciences, Medical Sciences Campus, University of Puerto Rico, PO Box 365067, San Juan PR 00936-5067, USA.

Received: 4 May 2012 Accepted: 21 August 2012

Published: 7 September 2012

\section{References}

1. Cabrera-Vera TM, Vanhauwe J, Thomas TO, Medkova M, Preininger A, Mazzoni MR, Hamm HE: Insights into G protein structure, function, and regulation. Endocr Rev 2003, 24(6):765-781.

2. McCudden CR, Hains MD, Kimple RJ, Siderovski DP, Willard FS: G-protein signaling: back to the future. Cell Mol Life Sci 2005, 62(5):551-577.

3. Oldham WM, Hamm HE: Structural basis of function in heterotrimeric $G$ proteins. Q Rev Biophys 2006, 39(2):117-166.

4. Preininger $\mathrm{AM}$, Hamm HE: $\mathrm{G}$ protein signaling: insights from new structures. SCi STKE 2004, 218:re3.

5. Holinstat M, Oldham WM, Hamm HE: G-protein-coupled receptors: evolving views on physiological signalling: symposium on G-proteincoupled receptors: evolving concepts and new techniques. EMBO Rep 2006, 7(9):866-869

6. Thomas $P$ : Characteristics of membrane progestin receptor alpha (mPRalpha) and progesterone membrane receptor component 1 (PGMRC1) and their roles in mediating rapid progestin actions. Front Neuroendocrinol 2008, 29(2):292-312.

7. Tang YT, Hu T, Arterburn M, Boyle B, Bright JM, Emtage PC, Funk WD: PAQR proteins: a novel membrane receptor family defined by an ancient 7-transmembrane pass motif. J Mol Evol 2005, 61(3):372-380.

8. Zhu Y, Bond J, Thomas P: Identification, classification, and partial characterization of genes in humans and other vertebrates homologous to a fish membrane progestin receptor. Proc Natl Acad Sci USA 2003, 100(5):2237-2242.

9. Zhu Y, Rice CD, Pang Y, Pace $M$, Thomas P: Cloning, expression, and characterization of a membrane progestin receptor and evidence it is an intermediary in meiotic maturation of fish oocytes. Proc Natl Acad Sci USA 2003, 100(5):2231-2236.

10. Zhu Y, Hanna RN, Schaaf MJ, Spaink HP, Thomas P: Candidates for membrane progestin receptors-past approaches and future challenges. Comp Biochem Physiol C Toxicol Pharmacol 2008, 148(4):381-389.

11. Thomas P, Zhu Y, Pace M: Progestin membrane receptors involved in the meiotic maturation of teleost oocytes: a review with some new findings. Steroids 2002, 67(6):511-517.

12. Thomas P, Pang Y, Dong J, Groenen P, Kelder J, de Vlieg J, Zhu Y, Tubbs C: Steroid and $\mathrm{G}$ protein binding characteristics of the seatrout and human progestin membrane receptor alpha subtypes and their evolutionary origins. Endocrinology 2007, 148(2):705-718.

13. Garitaonandia I, Smith JL, Kupchak BR, Lyons TJ: Adiponectin identified as an agonist for PAQR3/RKTG using a yeast-based assay system. J Recept Signal Transduct Res 2009, 29(1):67-73.

14. Kim JY, Scherer PE: Adiponectin, an adipocyte-derived hepatic insulin sensitizer regulation during development. Pediatr Endocrinol Rev 2004, 1(Suppl 3):428-431.

15. Pajvani UB, Scherer PE: Adiponectin: systemic contributor to insulin sensitivity. Curr Diab Rep 2003, 3(3):207-213.

16. Nawrocki AR, Rajala MW, Tomas E, Pajvani UB, Saha AK, Trumbauer ME, Pang Z, Chen AS, Ruderman NB, Chen $\mathrm{H}$, et al: Mice lacking adiponectin show decreased hepatic insulin sensitivity and reduced responsiveness to peroxisome proliferator-activated receptor gamma agonists. J Biol Chem 2006, 281(5):2654-2660.

17. Thomas P, Dressing G, Pang Y, Berg H, Tubbs C, Benninghoff A, Doughty K Progestin, estrogen and androgen $\mathrm{G}$-protein coupled receptors in fish gonads. Steroids 2006, 71(4):310-316.

18. Hanna RN, Zhu Y: Expression of membrane progestin receptors in zebrafish (Danio rerio) oocytes, testis and pituitary. Gen Comp Endocrinol 2009, 161(1):153-157.

19. Bayaa M, Booth RA, Sheng Y, Liu XJ: The classical progesterone receptor mediates xenopus oocyte maturation through a nongenomic mechanism. Proc Natl Acad Sci USA 2000, 97(23):12607-12612

20. Villa NY, Moussatche P, Chamberlin SG, Kumar A, Lyons TJ: Phylogenetic and preliminary phenotypic analysis of yeast PAQR receptors: potential antifungal targets. J Mol Evol 2011, 73(3-4):134-152.

21. Baida GE, Kuzmin NP: Mechanism of action of hemolysin III from Bacillus cereus. Biochim Biophys Acta 1996, 1284(2):122-124.

22. Lyons TJ, Villa NY, Regalla LM, Kupchak BR, Vagstad A, Eide DJ: Metalloregulation of yeast membrane steroid receptor homologs. Proc Natl Acad Sci USA 2004, 101(15):5506-5511.

23. Kupchak BR, Villa NY, Kulemina LV, Lyons TJ: Dissecting the regulation of yeast genes by the osmotin receptor. Biochem Biophys Res Commun 2008, 374(2):210-213.

24. Villa NY, Kupchak BR, Garitaonandia I, Smith JL, Alonso E, Alford C, Cowart $L A$, Hannun YA, Lyons TJ: Sphingolipids function as downstream effectors of a fungal PAQR. Mol Pharmacol 2009, 75(4):866-875.

25. Shankar J, Restrepo A, Clemons KV, Stevens DA: Hormones and the resistance of women to paracoccidioidomycosis. Clin Microbiol Rev 2011, 24(2):296-313.

26. Powell BL, Drutz DJ, Huppert M, Sun SH: Relationship of progesteroneand estradiol-binding proteins in Coccidioides immitis to coccidioidal dissemination in pregnancy. Infect Immun 1983, 40(2):478-485.

27. Bavec A, Slajpah M, Lenasi H, Yorko M, Breskvar K: G-protein coupled progesterone receptors in the plasma membrane of fungus Rhizopus nigricans. Pflugers Arch 2000, 440(5 Suppl):R179-R180.

28. Lenasi H, Slajpah M, Sterle M, Hudnik-Plevnik T, Breskvar K: Characterization of plasma membrane fraction from filamentous fungus Rhizopus Nigricans. Pflugers Arch 2000, 439(3 Suppl):R137-138.

29. Lenasi H, Bavec A, Zorko M: Membrane-bound progesterone receptors coupled to $\mathrm{G}$ proteins in the fungus Rhizopus Nigricans. FEMS Microbiol Lett 2002, 213(1):97-101.

30. Jeraj N, Stilla A, Petric S, Di Girolamo M, Cresnar B, Lenasi H: Identification and partial characterization of Rhizopus nigricans Gbeta proteins and 
their expression in the presence of progesterone. J Steroid Biochem Mol Biol 2010, 129(1-2):99-105.

31. Thomas PD, Campbell MJ, Kejariwal A, Mi H, Karlak B, Daverman R, Diemer K, Muruganujan A, Narechania A, PANTHER: A library of protein families and subfamilies indexed by function. Genome Res 2003, 13(9):2129-2141.

32. Krogh A, Larsson B, von Heijne G, Sonnhammer EL: Predicting transmembrane protein topology with a hidden Markov model: application to complete genomes. J Mol Biol 2001, 305(3):567-580.

33. Hirokawa T, Boon-Chieng S, Mitaku S, SOSUI: Classification and secondary structure prediction system for membrane proteins. Bioinformatics 1998, 14(4):378-379.

34. Buchan DW, Ward SM, Lobley AE, Nugent TC, Bryson K, Jones DT: Protein annotation and modelling servers at University College London. Nucleic Acids Res 2010, 38(Web Server issue):W563-W568.

35. Nakai $K$, Horton P, PSORT: A program for detecting sorting signals in proteins and predicting their subcellular localization. Trends Biochem Sci 1999, 24(1):34-36.

36. Small I, Peeters N, Legeai F, Lurin C, Predotar: A tool for rapidly screening proteomes for $\mathrm{N}$-terminal targeting sequences. Proteomics 2004, 4(6):1581-1590.

37. Emanuelsson $\mathrm{O}$, Brunak $\mathrm{S}$, von Heijne $\mathrm{G}$, Nielsen $\mathrm{H}$ : Locating proteins in the cell using targetP, signalP and related tools. Nat Protoc 2007 2(4):953-971.

38. Narasimhan ML, Coca MA, Jin J, Yamauchi T, Ito Y, Kadowaki T, Kim KK, Pardo JM, Damsz B, Hasegawa PM, et al: Osmotin is a homolog of mammalian adiponectin and controls apoptosis in yeast through a homolog of mammalian adiponectin receptor. Mol Cell 2005, 17(2):171-180.

39. Smith JL, Kupchak BR, Garitaonandia I, Hoang LK, Maina AS, Regalla LM, Lyons TJ: Heterologous expression of human mPRalpha, mPRbeta and mPRgamma in yeast confirms their ability to function as membrane progesterone receptors. Steroids 2008, 73(11):1160-1173.

40. Yoshikuni M, Nagahama Y: Involvement of an inhibitory G-protein in the signal transduction pathway of maturation-inducing hormone (17 alpha,20 beta-dihydroxy-4-pregnen-3-one) action in rainbow trout (Oncorhynchus mykiss) oocytes. Dev Biol 1994, 166(2):615-622.

41. Yamauchi T, Kamon J, Ito Y, Tsuchida A, Yokomizo T, Kita S, Sugiyama T, Miyagishi M, Hara K, Tsunoda M, et al: Cloning of adiponectin receptors that mediate antidiabetic metabolic effects. Nature 2003, 423(6941):762-769.

42. Das M, Datta A: Steroid binding protein(s) in yeasts. Biochem Int 1985, 11(2):171-176.

43. Banerjee D, Pillai B, Karnani N, Mukhopadhyay G, Prasad R: Genome-wide expression profile of steroid response in Saccharomyces cerevisiae. Biochem Biophys Res Commun 2004, 317(2):406-413.

44. Prasad R, Devaux F, Dhamgaye S, Banerjee D: Response of pathogenic and non-pathogenic yeasts to steroids. J Steroid Biochem Mol Biol 2012, 129(1-2):61-69.

45. Kupchak BR, Garitaonandia I, Villa NY, Mullen MB, Weaver MG, Regalla LM, Kendall EA, Lyons TJ: Probing the mechanism of FET3 repression by Izh2p overexpression. Biochim Biophys Acta 2007, 1773(7):1124-1132.

46. Phelps C, Gburcik V, Suslova E, Dudek P, Forafonov F, Bot N, MacLean M, Fagan RJ, Picard D: Fungi and animals may share a common ancestor to nuclear receptors. Proc Natl Acad Sci USA 2006, 103(18):7077-7081.

47. Krishnamurthy S, Gupta V, Prasad R, Panwar SL: Expression of CDR1, a multidrug resistance gene of Candida albicans: transcriptional activation by heat shock, drugs and human steroid hormones. FEMS Microbiol Lett 1998, 160(2):191-197.

48. Poli A, Di Pietro A, Zigon D, Lenasi H: Possible involvement of G-proteins and CAMP in the induction of progesterone hydroxylating enzyme system in the vascular wilt fungus Fusarium oxysporum. J Steroid Biochem Mol Biol 2009, 113(3-5):241-247.

49. Jeraj $\mathrm{N}$, Lenasi $H$, Breskvar $\mathrm{K}$ : The involvement of CAMP in the growth inhibition of filamentous fungus Rhizopus nigricans by steroids. FEMS Microbiol Lett 2005, 242(1):147-154.

50. Thomas P, Tubbs C, Garry VF: Progestin functions in vertebrate gametes mediated by membrane progestin receptors (mPRs): identification of mPRalpha on human sperm and its association with sperm motility. Steroids 2009, 74(7):614-621.

51. Tubbs $C$, Thomas P: Progestin signaling through an olfactory $G$ protein and membrane progestin receptor-alpha in Atlantic croaker sperm: potential role in induction of sperm hypermotility. Endocrinology 2009, 150(1):473-484.
52. Visbal G, San-Blas G, Maldonado A, Alvarez-Aular A, Capparelli MV, Murgich $\mathrm{J}$ : Synthesis, in vitro antifungal activity and mechanism of action of four sterol hydrazone analogues against the dimorphic fungus Paracoccidioides brasiliensis. Steroids 2011, 76(10-11):1069-1081.

53. Betancourt S, Torres-Bauza LJ, Rodriguez-Del Valle N: Molecular and cellular events during the yeast to mycelium transition in Sporothrix schenckii. Sabouraudia 1985, 23(3):207-218.

54. Delgado N, Rodriguez-del Valle N: Presence of a pertussis toxin-sensitive G protein alpha subunit in Sporothrix schenckii. Med Mycol 2000, 38(2):109-121.

55. Valentin-Berrios S, Gonzalez-Velazquez W, Perez-Sanchez L, GonzalezMendez R, Rodriguez-Del Valle N: Cytosolic phospholipase A2: a member of the signalling pathway of a new G protein alpha subunit in Sporothrix schenckii. BMC Microbiol 2009, 9:100.

56. Aquino-Pinero EE, Rodriguez Del Valle N: Different protein kinase C isoforms are present in the yeast and mycelium forms of Sporothrix schenckii. Mycopathologia 1997, 138(3):109-115.

57. Altschul SF, Gish W, Miller W, Myers EW, Lipman DJ: Basic local alignment search tool. J Mol Biol 1990, 215(3):403-410.

58. Ikeda M, Arai M, Lao DM, Shimizu T: Transmembrane topology prediction methods: a re-assessment and improvement by a consensus method using a dataset of experimentally-characterized transmembrane topologies. In Silico Biol 2002, 2(1):19-33.

59. Claros MG, MitoProt: A macintosh application for studying mitochondrial proteins. Comput Appl Biosci 1995, 11(4):441-447.

60. Notredame C, Higgins DG, Heringa J: T-coffee: a novel method for fast and accurate multiple sequence alignment. J Mol Biol 2000, 302(1):205-217.

doi:10.1186/1471-2180-12-194

Cite this article as: Gonzalez-Velazquez et al:: Characterization and ligand identification of a membrane progesterone receptor in fungi: existence of a novel PAQR in Sporothrix schenckii. BMC Microbiology 2012 12:194.

\section{Submit your next manuscript to BioMed Central and take full advantage of:}

- Convenient online submission

- Thorough peer review

- No space constraints or color figure charges

- Immediate publication on acceptance

- Inclusion in PubMed, CAS, Scopus and Google Scholar

- Research which is freely available for redistribution

Submit your manuscript at www.biomedcentral.com/submit
C) Biomed Central 